\section{PRODUCTION}

ENGINEERING ARCHIVES
2014, Vol. 5, No 4, pp 14-17

ISSN 2353-5156

ISSN 2353-7779 (print version)

(online version)

Article history: Received: 10.09.2014

Accepted: 25.09.2014

Online: 31.12 .2014

Available online on: http://www.qpij.pl

Exist since $4^{\text {th }}$ quarter 2013

\title{
Production management of window handles
}

\author{
Manuela Ingaldi ${ }^{1}$, Marta Jagusiak-Kocik ${ }^{2}$ \\ ${ }^{1}$ Institute of Production Engineering, Faculty of Management, Czestochowa University of Technology, Armii Krajowej 19B, 42-201 \\ Czestochowa, Poland, e-mail: Manuela@gazeta.pl \\ ${ }^{2}$ Institute of Production Engineering, Faculty of Management, Czestochowa University of Technology, Armii Krajowej 19B, 42-201 \\ Czestochowa, Poland, e-mail: m.jagusiak-kocik@o2.pl
}

\begin{abstract}
In the chapter a company involved in the production of aluminum window and door handles was presented. The main customers of the company are primarily companies which produce PCV joinery and wholesalers supplying these companies. One chosen product from the research company - a single-arm pin-lift window handle - was described and its production process depicted technologically. The chapter also includes SWOT analysis conducted in the research company and the value stream of the single-arm pin-lift window handle.
\end{abstract}

Key words single-arm pin-lift window handle, production process depicted technologically, value stream

\section{Introduction}

The company which was used as a research facility manufactures aluminum door and window handles. The main customers of the company are companies which produce PCV joinery and wholesalers supplying these companies. The main export markets are: Austria, Czech Republic, Slovakia, Lithuania, Latvia, Hungary, Belarus and Estonia.

The window handles, which are made of aluminum, have very good utilization properties: are resistant and have a high aesthetic value. The technology, which is used during production process of the window handles with use of this material, depends on coats the company wants to get on the window handles. The die casting allows one to obtain a varnishing coat (handles white, brown) and anodized coats (effects of silver, gold, dark gold). Pressure die casting is a competitive technology, the disadvantage being the inability of anodized coats (varnish only). However, the costs of production of aluminum handles with this technology are much smaller, because it is used as a handle for PVC windows, which mainly require the fitting of white or brown ferrules.

The main products produced by the research company are: window handles available in aluminum and plastic (color white and bronze), aluminum window handles (color bright and dark silver and gold), aluminum window handles with a lock (color white and bronze) and aluminum door handles (color white and bronze).

\section{Characteristics of the research product}

The object of the research presented in this chapter is a single-arm pin-lift window handle. It is designed for hardware mechanisms of swing, tilt-swing, and tilt ferrules, which are mounted in the windows and balcony doors made of wood, aluminum and plastics. In Figure 1 basic elements of the single-arm pin-lift window handle are presented. Figure 1 shows that, the 
single-arm pin-lift window handle consists of tang (element 1), arbor (element 2), masking frame - cover (element 3) and shield (element 4), fixing sleeve (element 5) and screw (element 6).

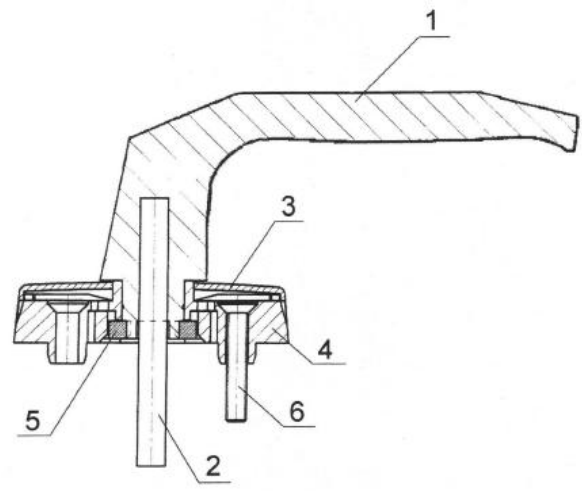

Fig. 1. Basic elements of the single-arm pin-lift window handle.

Source: own study based on materials from the research company

The elements of the single-arm pin-lift window handle consists of tang are made of aluminium or zinc, and their surface is powder varnished. Steel arbors of the handles are covered with a galvanic zinc coat.

\section{The production process of the research product}

Production process of the single-arm pin-lift window handle depicted technologically is presented in Figure 2.

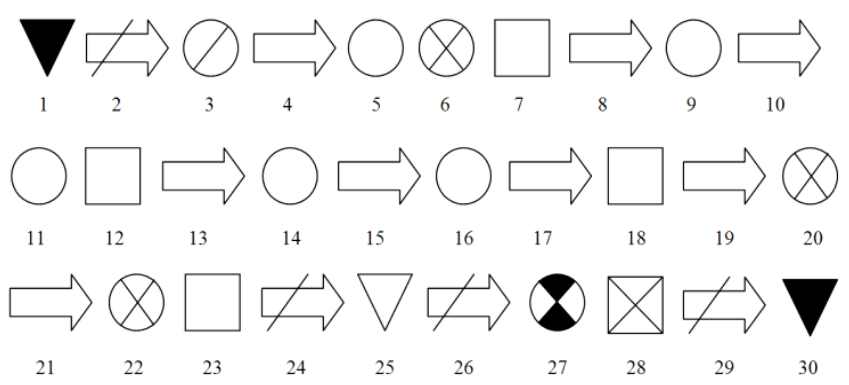

Fig. 2. Production process of the single-arm pin-lift window handle depicted technologically.

Source: own study

Characteristics of the route points (BORKOWSKI S., UlEWICZ R. 2008, BURCHART-Korol D., FURMAN J. 2007, DURLIK I.1998, INGALDI M., JAGUSIAK-KoCIK M., SYGUT P. 2013):
1. Storage of the aluminium. 2. Transport of the aluminium to furnace. 3. Melting of the aluminium in the crucible. 4. Transport liquid aluminium to grout the sleeve of the casting machine. 5. Shaping of the handle in a pressure machine by injection of aluminium into the mould. 6. Separation of the gating system and the handle cast 7. Quality control of the alloys and dimension. 8. Transport of the handle to the first barrelling in the vibration machine. 9. Barrelling of the handle to remove the riser head. 10. Transport of the handle to grindery. 11. Grinding of the handle in order to give proper shape. 12. Quality control of the handle after grinding. 13. Transport of the handle to the first barrelling in the vibration machine. 14. Barrelling of the handle before applying a coat of varnish. 15. Transport of the handle to heating tunnel. 16. Heat treatment removing water and impurities. 17. Transport of the handle to powder paint. 18. Quality control. 19. Transport of the handle to powder cabin. 20. Application of powder paint on the handle. 21. Transport of the handle to holding furnace. 22. Holding of the handle in order to finish the varnish coat. 23. Quality control of the handle after varnishing. 24. Transport of the handle to storage. 25. Storage of the semi-products. 26. Transport of the handle to assembly hall. 27. Assembly of the storage. 28. Final quality control. 29. Transport of the handle to a place of storing final products. 30 . Storage of the final products.

\section{SWOT analysis for the research company}

The SWOT method (GIERSZEWSKA G., ROMANOWSKA M. 1997; INGALDI M., JAGUSIAKKociK M. 2013; JaguSIaK M., UlewiCZ R., ŚWIDER A. 2009) is a tool used for internal analysis and its business environment in order to optimise management strategy of the company or creation of the new strategic plan. An organization, project or investment as well as any event in the field of business can be analysed. The main goal of the SWOT analysis is to determine the current position of the research object and its prospects, and with the best strategy for working. Its name comes from the first letters of each considered group of elements: strengths - everything that is an asset, predominance, advantage of the analysed object, weaknesses - everything that is a weakness, 
barrier, defect of the analysed object, opportunities everything that makes a favourable opportunity, chance, change for the research object, threats - everything that causes a risk of unfavourable changes for the research object.

SWOT analysis for the research company is presented in Table 1.

Table 1. SWOT analysis for the research company

\begin{tabular}{|c|c|c|c|}
\hline Strengths $(\mathbf{S})$ & Point & Weaknesses $(\mathbf{W})$ & Point \\
\hline 1. New machinery & 7 & $\begin{array}{c}\text { 1. Lack of competitive } \\
\text { advantage }\end{array}$ & 6 \\
\hline $\begin{array}{c}\text { 2. Good location of } \\
\text { the company }\end{array}$ & 7 & $\begin{array}{l}\text { 2. Small number of } \\
\text { representatives }\end{array}$ & 6 \\
\hline 3. Brand recognition & 7 & \multirow{4}{*}{ 3. High unit cost } & \multirow{4}{*}{7} \\
\hline 4. Just in time & 8 & & \\
\hline $\begin{array}{l}\text { 5. High quality of the } \\
\text { product }\end{array}$ & 8 & & \\
\hline $\begin{array}{c}\text { 6. Experience man- } \\
\text { agement team }\end{array}$ & 7 & & \\
\hline$\sum$ & 444 & $\sum$ & 19 \\
\hline Opportunities (O) & Point & Threats (T) & Point \\
\hline $\begin{array}{l}\text { 1. The emergence of } \\
\text { the new groups of } \\
\text { customers }\end{array}$ & 8 & $\begin{array}{l}\text { 1. Possibility of } \\
\text { emergence of the } \\
\text { new competitors }\end{array}$ & 8 \\
\hline $\begin{array}{c}\text { 2. Possibility of the } \\
\text { extending of as- } \\
\text { sortment }\end{array}$ & 8 & $\begin{array}{l}\text { 2. Increase in trans- } \\
\text { port cost }\end{array}$ & 7 \\
\hline $\begin{array}{l}\text { 3. Improvement of the } \\
\text { management team }\end{array}$ & 10 & $\begin{array}{l}\text { 3. Risk of losing } \\
\text { customers }\end{array}$ & 6 \\
\hline $\begin{array}{c}\text { 4. Openness to } E U \\
\text { markets }\end{array}$ & 9 & $\begin{array}{l}\text { 4. Change of needs } \\
\text { and tastes of custom- } \\
\text { ers }\end{array}$ & 6 \\
\hline $\bar{\Sigma}$ & 35 & $\sum$ & 27 \\
\hline
\end{tabular}

Source: own study

In Figure 3 graphic interpretation of the SWOT analysis and current strategic position of the research company is presented.

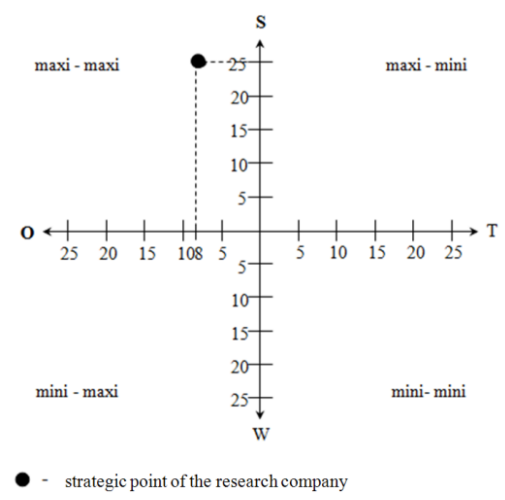

Fig. 3. Graphic interpretation of the SWOT analysis for the research company.

Source: own study
From Figure 3 the results suggest that the company is in the maxi-maxi position. This position means the strengths of the research company dominated its weaknesses and the opportunities dominated threats. This is a strong development expansion strategy, to enter new markets, invest and continue to build competitive advantage. The maxi-maxi position means a privileged position in the market. The strategy the company should work towards is maintaining this position. The SWOT strategy maxi-maxi position is an aggressive strategy.

\section{Presentation of the value stream of the single-arm pin-lift window handle}

The value stream (CZERSKA J. 2009; ROTHER M., SHOOK J. 2009; WOMACK J. P., JONES D.T. 2008) is a set of all actions (those that add and which do not add value in the process), which are required for a particular product or service.

In Figure 4 the value stream of the single-arm pinlift window handle is presented.

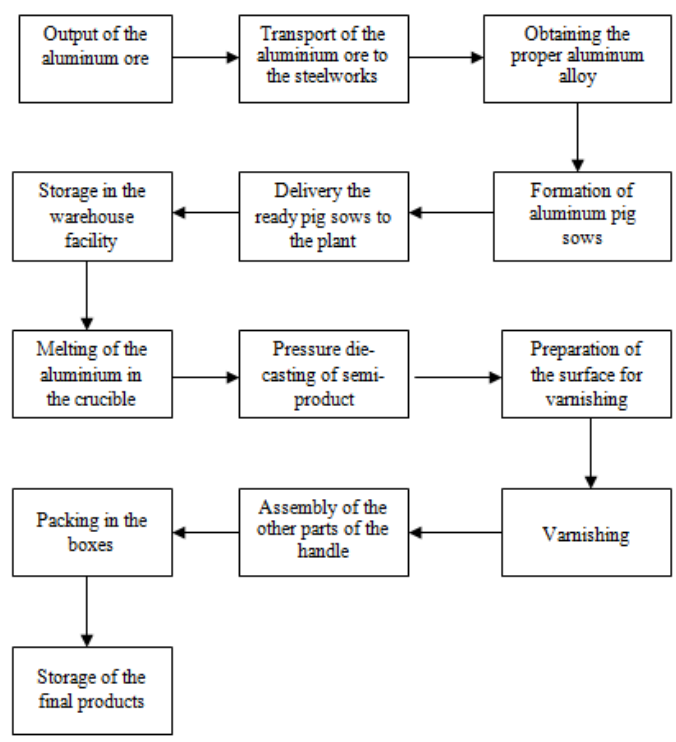

Fig. 4. Value stream of the single-arm pin-lift window handle.

Source: own study

Production process of the single-arm pin-lift window handle can be divided into 2 separate value streams, which are presented in Figure 5: value stream 
of output and processing of the iron ore, value stream of manufacturing of the handle.

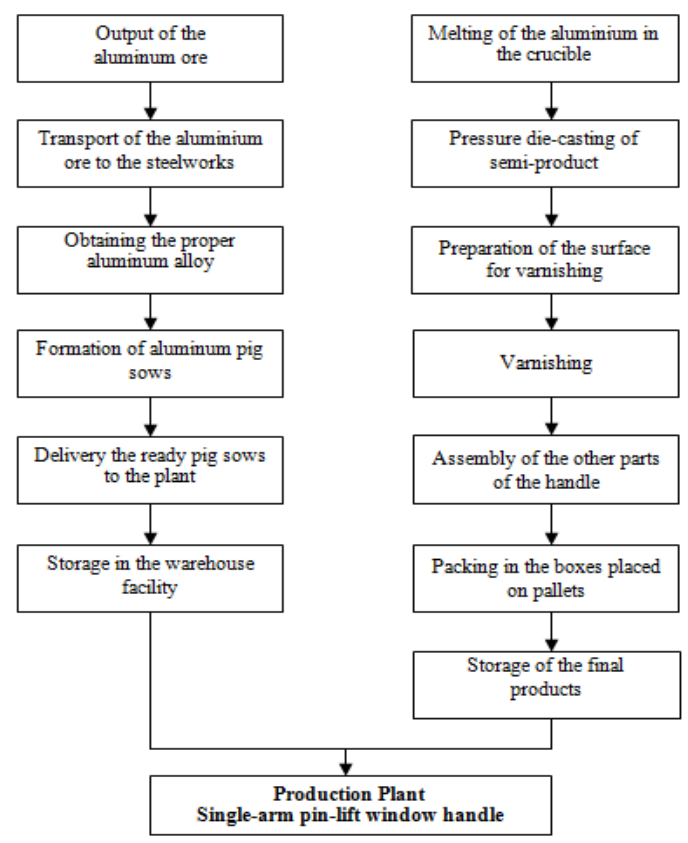

Fig. 5. Connection of 2 value streams during production of the single-arm pin-lift window handle.

Source: own study.

\section{Summary}

The company, implementing Lean Manufacturing objectives and identifying the value streams, has become more competitive in the markets in many countries, where there are exported manufactured goods. Limitation of the wastes has resulted in lower production costs, faster development of products and the simultaneous increase in customer satisfaction through faster delivery of goods ordered.

The use of the SWOT analysis allowed the identification of the strategic position of the research company in the market. It was concluded that the strengths of the research company overrided its weaknesses and the opportunities overrided its threats.

With large production capabilities and after joining the EU market, the company should try to obtain the best position in this market.

Through research and innovation capabilities, the company is able to deliver products using the latest technology, and thus meet the needs of the most de- manding customers, leading to the strengthening of the brand.

\section{References}

1. BORKOWSKI S., ULEWICZ R. 2008. Zarzadzanie produkcja. Systemy produkcyjne. Oficyna Wydawnicza „Humanitas". Sosnowiec.

2. Burchart-Korol D., Furman J. 2007. Zarzadzanie produkcja i ustugami. Wydawnictwo Politechniki Śląskiej. Gliwice.

3. CZERSKA J. 2009. Doskonalenie strumienia wartości. Centrum Doradztwa i Informacji Difin. Warszawa.

4. DURLIK I.1998. Inżynieria zarzadzania. Strategia i projektowanie systemów produkcyjnych Część I. Wydawnictwo PLACET. Warszawa.

5. GIERSZEWSKA G., RomANowsKA M. 1997. Analiza strategiczna przedsiębiorstwa. Polskie Wydawnictwa Ekonomiczne. Warszawa.

6. INGALDI M. 2013. Analysis of the quality problems during production process of the stud frame of the stretching station. Production Engineering Archives, 2/2013, p. 2-5.

7. INGALDI M., JAGUSIAK-KoCIK M. 2013. SWOT Analysis of the Process Improvement in the Company Producing Electric Sockets. Chapter 6. [In:] Toyotarity. Evoluation and Processes'/Products' Improvement. Monograph. INGALDI M., BORKOWSKI S. (Ed.). Aeternitas Publishing House. Alba Iulia. Romania.

8. JAGUSIAK-KoCIK M. 2013. Ensuring continuous improvement processes through standardization in the automotive company. Production Engineering Archives, 2/2013, p.12-15.

9. JAGUSiaK M., UlewiCz R., ŚWIDER A. 2009. Elements of visual control in metalwork. Chapter 2. In: Toyotarity. Visual Control. BORKOWSKI S., TsOY E.B. (ed.)., Publisher Yurii V. Makovetsky. Dnipropetrovsk.

10. SYGUT P. 2013. Process of quality improvement in the company producing building materials. Production Engineering Archives, 1/2013, p. 16-18.

11. WOMACK J. P., JONES D.T. 2008. Lean Thinking- szczupte myślenie. Wydawnictwo Prodpress. Wrocław. 